\title{
PENGARUH PEMBERIAN JUS BUAH DAN WARNA PADA PERANGKAP LIKAT TERHADAP JUMLAH TANGKAPAN LALAT BUAH DAN SERANGGA LAIN PADA PERTANAMAN CABAI MERAH
}

\author{
A. M. Kumbara, I Gede Swibawa, Agus M. Hariri \& Rosma Hasibuan \\ Jurusan Agroteknologi, Fakultas Pertanian, Universitas Lampung \\ J1. Prof. Soemantri Brojonegoro, No. 1 Bandar Lampung 35145
}

\begin{abstract}
ABSTRAK
Salah satu OPT yang sering menyerang dan menurunkan produksicabai merah adalah lalat buah. Penelitian ini bertujuan untuk mengetahui pengaruh warna pada papan perangkap dan pemberian jus buah terhadap jumlah tangkapan perangkap likat. Pemasangan perangkap likat dilaksanakan pada bulan Januari - Juni 2017 di Desa Candra Kencana, Kecamatan Tulang Bawang Tengah, Kabupaten Tulang Bawang Barat.Identifikasi serangga yang tertangkap di lakukan di Laboratorium Ilmu Hama Tumbuhan, Fakultas Pertanian, Universitas Lampung. Satuan Percobaan disusun dalam rancangan acak kelompok faktorial dengan 2 faktor $(3 \times 3)$ dengan 5 ulangan. Faktor I adalah jus yang terdiri dari 3 taraf : tanpa jus, jus jambu biji, dan jus belimbing. Faktor II adalah warna 3 taraf : tanpa warna (bening), warna hijau, dan warna kuning. Perangkap dipasang saat tanaman cabai mulai berbuah yaitu pada umur 12 minggu setelah tanam. Hasil penelitian ini menunjukkan bahwa penggunaan warna kuning pada papan likat memberikan jumlah tangkapan yang lebih tinggi daripada warna lainnya. Penambahan jus belimbing pada perangkap likat menghasilkan jumlah tangkapan yang lebih tinggi dibandingkan jus lainnya. Kombinasi perangkap likat warna kuning dengan penambahan jus buah belimbing menghasilkan jumlah tangkapan lebih tinggi daripada kombinasi warna dan jus buah lainnya.
\end{abstract}

Kata kunci: Lalat buah, jus buah, perangkap likat

\section{PENDAHULUAN}

Cabai merah termasuk dalam 10 komoditas hortikultura yang mendapat prioritas pengembangan pemerintah (Ditjen Hortikultura, 2008).Namun demikian produksi cabai merah di Indonesia mengalami penurunan dari 1.074.602 ton / ha pada tahun 2014 menjadi 1.045.182 ton / ha di tahun 2015. Penurunan produksi cabai merah dikarenakan masih tingginya serangan organisme penggangu tanaman (OPT). Salah satu OPT penting padacabai merah adalah lalat buah, yang termasuk dalam ordo Diptera, famili Tephritidae. Serangan lalat buah merugikan petani cabai merah, karena menyebabkan busuk pada buah.

Upaya menurunkanpopulasi hama lalat buah berbagai teknik pengendalian dapat diterapkan. Teknik pengendalian yang umum diterapkan petani cabai adalah teknik pengendalian secara kimiawi menggunakan insektisida atau secara mekanis dengan memetik buah yang busuk. Pengendalian secara kimiawi dapat berdampak negatif yaitu hama menjadi resisten dan buah cabai mengandung residu pestisida yang berbahaya bagi kesehatan konsumen. Oleh karena itu, perlu dilakukan teknik pengendalian alternatifyang efisien dan ramah lingkungan.
Penggunaan perangkap likat (sticky trap) merupakan salah satu teknik pengendalian yang ramah lingkungan dan dapat mnejadi pilihan alternatif. Teknik pengendalian dengan perangkap likat tidak menggunakan bahan beracun. Prinsip kerja perangkap likat adalah menangkap lalat buah dengaan cara menjebaknya pada papan likat.

Aktivitas lalat buah dalam menemukan tanaman inang dipengaruhi oleh warna dan bau buah. Lalat buah menyukai spektrum warna tertentu kerena memiliki selsel retina pada mata yang dapat membedakan warna (Gustilin, 2008). Oleh karena itu, pemberian warna pada perangkap likat akan mempengaruhi lalat untuk mendatangi perangkap.

Lalat buah dewasa tertarik terhadap senyawa aromatik yang terdapat pada bagian tanaman termasuk buahnya. Dengan berpedoman aktivitas ini, beberapa senyawa kimia digunakan sebagai atraktan lalat buah. Senyawa yang banyak digunakan sebagai atraktan lalat buah antara lain : 3,4-dimethoxy allibenzene atau methyl eugenol (ME), 1(pecetoxyphenyl)- butan-3 one atau cue lure (CL) dan t-butyl 4 (atau 5) chloro-2 methyl cyclohexanoate atau Trimediure. Lalat buah spesies Bactrocera dorsalis, B. muse, dan B. umbrosus sangat tertarik terhadap methyl eugenol (ME), lalat 
jantan Bactrocera cucurbitae dan B. trivialis tertarik pada cue lure (CL), sedangkan lalat jantan Ceracitis capitata tertarik pada trimediure (Fletcher, 1987 ; Putra, 1997).

Dengan memperhatikan aktivitas lalat buah yang tertatrik warna dan aroma buah, maka sticky trap dapat dibuat dengan mengkombinasikan warna dan jus buah yang mengeluarkan senyawa aromatik. Aplikasi sticky trap yang dibuat dari kombinasi warna dengan jus yang mengeluarkan aroma buah belum banyak dipelajari. Informasi tentang pengaruh pemberian warna dan jus buah pada perangkap berperekat terhadap jumlah tangkapan lalat buah di pertanaman cabai merah bermanfaat. Informasi semacam ini dapat memberikan gambaran teknik alternatif yang dapat digunakan untuk pengendalian lalat buah. Informasi semacam ini juga bermanfaat sembagai sumber referensi untuk penelitian berikutnya.Penelitian ini bertujuan untuk mengetahui pengaruh warna pada papan perangkap dan pemberian jus buah terhadap jumlah tangkapan perangkap likat.

\section{BAHAN DAN METODE}

Penelitian dilaksanakan pada pertanaman cabai di Desa Candra Kencana, Kecamatan Tulang Bawang Tengah, Kabupaten Tulang Bawang Barat dan Laboratorium Ilmu Hama Tumbuhan, Jurusan Agroteknologi, Fakultas Pertanian, Universitas Lampung. Penelitian ini dilaksanakan pada bulan Januari - Juni 2017.

Percobaan menggunakan rancangan faktorial disusun dalam Rancangan Acak Kelompok dengan 9 perlakuan dan 5 ulangan. Sebagai perlakuan adalah $\mathrm{W} 0 \mathrm{~J} 0=$ Tanpa warna dan tanpa jus buah, $\mathrm{W} 0 \mathrm{~J} 1=$ Tanpa warna dengan jus jambu biji, W0J2 = Tanpa warna dengan jus belimbing, $\mathrm{W} 1 \mathrm{~J} 0=$ Warna hijau dan tanpa jus buah, W1J1 = Warna hijau dengan jus jambu biji, $\mathrm{W} 1 \mathrm{~J} 2=$ Warna hijau dengan jus belimbing, W2J0 = Warna kuning dan tanpa jus buah, W2J1 = Warna kuning dengan jus jambu biji, W2J2 = Warna kuning dengan jus belimbing. Perangkap likat dibuat dari papan kayu ( triplek) yang dibuat berbentuk limas. Papan kayu (triplek) berukuran $30 \mathrm{~cm} \times 15 \mathrm{~cm}$ dibuat sebagai alas dan bamboo berukuran $15 \mathrm{~cm}$ dibuat sebagai tiang. Bambu dipasang pada kedua sisi triplek kemudian kawat untuk membuat rangka berbentuk seperti atap rumah ( limas). Botol air mineral $50 \mathrm{ml}$ yang telah dipotong 2 bagian berisi jus buah dipasang pada bagian tengah alas perangkap. Kertas buffalo bewarna yang d lapisi pelastik mika dipasang pada kerangka kawat. Pada dua sisi dibiarka terbuka agar aroma jus buah dapat menyebar keluar dan menarik hama untuk mendatangi perangkap. Perangkap likat yang dibuat dari kombinasi warna dan jus buah sebagai satuan percobaan dipasang secara acak pada setiap blok areal pertanaman cabai. Total perangkap yang dipasang sebanyak 45 perangkap. Perangkap dipasang saat tanaman cabai mulai berbuah pada umur 12 minggu setelah tanam.

Variabel yang diamati adalah jumlah lalat buah yang tertangkap, lalat lain dan serangga lain yang tertangkap. Homogenitas ragam data di uji dengan uji Bartlet, kemudian dilanjutkan dengan analisis ragam dan pemisahan nilai tengah dengan uji BNT pada taraf $5 \%$. Semua pengujian statistik menggunakan program Microsoft excel 2010.

\section{HASIL DAN PEMBAHASAN}

\section{Hasil Penelitian}

Hasil penelitian menunjukkan bahwa serangga yang tertangkap meliputi lalat buah (Bactrocera dorsalis), lalat lain, dan serangga lain. Hasil analisis ragam menunjukkan bahwa terjadi interaksi antara pemberian warna dengan jus buah pada perangkap likat terhadap jumlah lalat buah, jumlah lalat lain, dan serangga lainnya yang tertangkap (Tabel 1).

Lalat Buah Tertangkap. Hasil analisis ragam menunjukkan bahwa terjadi interaksi yang nyata antara pemberian warna dengan jus buah pada perangkap likat terhadap jumlah lalat buah tertangkap (Tabel 1). Interaksi

Tabel 1. Nilai $\mathrm{F}$ hitung analisis ragam pengaruh pemberian warna dan jus buah pada perangkap likat terhadap jumlah tangkapan lalat buah (Bactrocera dorsalis), lalat lain dan serangga lain pada pertanaman cabai merah

\begin{tabular}{lccc}
\hline \multirow{2}{*}{ Variabel Pengamatan } & \multicolumn{3}{c}{ Nilai F-hitung } \\
\cline { 2 - 4 } & Warna (W) & Jus $(\mathrm{J})$ & W x J \\
\hline Jumlah la lat buah & $55,45^{*}$ & $19,56^{*}$ & $12,08^{*}$ \\
Jumlah la lat lain & $19,08^{*}$ & $4,93^{*}$ & $15,22^{*}$ \\
Jumlah serangga lain & $26,80^{*}$ & $8,75^{*}$ & $11,14^{*}$ \\
\hline
\end{tabular}

Keterangan: $*$ = berpengaruh nyata pada taraf $=5 \%$ 
yang terjadi menyebabkan terdapat perbedaan jumlah lalat buah yang tertangkap pada masing-masing kombinasi perlakuan (Tabel 2). Interaksi W x J (Tabel 3) menunjukkan bahwa perangkap dengan jus jambu dan warna kuning pada papan likat yang diberi jus jambu memiliki rata-rata jumlah lalat buah yang tertangkap lebih tinggi $(2,80)$ tidak berbeda nyata dengan warna hijau $(2,40)$ tetapi lebih tinggi dibandingkan dengan tanpa warna $(0,80)$.

Hasil serupa juga didapatkan dengan penggunaan tanpa jus untuk rata-rata jumlah lalat buah tertangkap. Selain itu, penggunaan warna kuning pada papan likat memiliki rata-rata jumlah lalat buah yang tertangkap lebih tinggi $(3,60)$ jika dibandingkan warna lainnya dengan menggunakan jus belimbing. Penambahan jus belimbing memiliki rata-ratajumlah lalat tertangkap lebih tinggi $(3,60)$ jika dibandingkan dengan jus jambu biji $(2,80)$ dan tanpa jus $(2,00)$ pada papan likat warna kuning. Tanpa penambahan jus memiliki rata-rata jumlah lalat tertangkap lebih rendah $(1,40)$ jika dibandingkan dengan jus jambu biji $(2,40)$ dan jus belimbing $(2,60)$ pada papan likat warna hijau. Penggunaan jus belimbing memiliki rata-rata jumlah lalat buah yang tertangkap lebih tinggi $(1,20)$ dan tidak berbeda nyata dengan jus jambu biji $(0,80)$ jika dibandingkan dengan tanpa jus $(0,40)$. Secara keseluruhan berdasarkan nilai BNT pada taraf $5 \%(0,67)$, penggunaan warna kuning pada papan likat dengan penambahan jus belimbing memiliki rata-rata jumlah lalat buah tertangkap lebih tinggi $(3,60)$ jika dibandingkan dengan kombinasi lainnya.

Lalat Lain Tertangkap. Hasil analisis ragam menunjukkan bahwa terjadi interaksi yang nyata antara pemberian warna dengan jus buah pada perangkap likat mempengaruhi jumlah lalat lainnya (Tabel 4). Interaksi yang terjadi menyebabkan terdapat perbedaan jumlah lalat lainnya yang tertangkap pada masing-masing kombinasi perlakuan (Tabel 3).

Warna kuning pada papan likat memiliki rata-rata jumlah lalat lainnya yang tertangkap sebanyak $(64,60)$ dan tidak berbeda nyata dengan warna hijau yaitu $(51,60)$ jika dibandingkan dengan tanpa warna $(33,80)$ apabila dikombinasikan dengan jus jambu biji. Hasil serupa juga

Tabel 2. Pengaruh interaksi $\mathrm{W}$ x J terhadap jumlah lalat buah yang tertangkap pada papan likat

\begin{tabular}{lccc}
\hline \multirow{2}{*}{ Warna } & \multicolumn{3}{c}{ Jus } \\
\cline { 2 - 4 } & Tanpa jus & Jambu biji & Belimbing \\
\hline Tanpa Warna (Bening) & $0,40 \mathrm{~b}$ & $0,80 \mathrm{ab}$ & $1,20 \mathrm{a}$ \\
\multirow{2}{*}{ Hijau } & $\mathrm{B}$ & $\mathrm{B}$ & $\mathrm{C}$ \\
\multirow{4}{*}{ Kuning } & $1,40 \mathrm{~b}$ & $2,40 \mathrm{a}$ & $2,60 \mathrm{a}$ \\
& $\mathrm{A}$ & $\mathrm{A}$ & $\mathrm{B}$ \\
& $2,00 \mathrm{c}$ & $2,80 \mathrm{~b}$ & $3,60 \mathrm{a}$ \\
& $\mathrm{A}$ & $\mathrm{A}$ & $\mathrm{A}$ \\
\hline
\end{tabular}

$\overline{\text { Keterangan: Nilai tengah yang diikuti oleh huruf yang sama dinyatakan tidak berbeda nyata menurut }}$ uji BNT pada taraf $=5 \%$. Huruf kecil dibaca mendatar dan huruf besar dibaca menurun

Tabel 3. Pengaruh interaksi W x J terhadap jumlah lalat lainnya yang tertangkap pada papan likat

\begin{tabular}{|c|c|c|c|}
\hline \multirow[b]{2}{*}{ Warna } & \multicolumn{3}{|c|}{ Jus } \\
\hline & Tanpa Jus & Jambu biji & Belimbing \\
\hline \multirow[t]{2}{*}{ Tanpa Warna (Bening) } & $28,80 \mathrm{a}$ & $33,80 \mathrm{a}$ & $39,00 \mathrm{a}$ \\
\hline & B & B & B \\
\hline \multirow[t]{2}{*}{ Hijau } & $35,60 \mathrm{~b}$ & $51,60 \mathrm{ab}$ & $64,00 \mathrm{a}$ \\
\hline & B & A & A \\
\hline \multirow[t]{2}{*}{ Kuning } & $61,00 \mathrm{a}$ & $64,60 \mathrm{a}$ & $70,40 \mathrm{a}$ \\
\hline & A & A & A \\
\hline
\end{tabular}

Keterangan: Nilai tengah yang diikuti oleh huruf yang sama dinyatakan tidak berbeda nyata menurut uji BNT pada taraf $=5 \%$. Huruf kecil dibaca mendatar dan huruf besar dibaca menurun 
Tabel 4. Pengaruh interaksi $\mathrm{W} x \mathrm{~J}$ terhadap jumlah serangga lain yang tertangkap pada papan likat

\begin{tabular}{lcccc}
\hline \multirow{2}{*}{ Warna } & \multicolumn{3}{c}{ Jus } \\
\cline { 2 - 5 } & Tanpa Jus & Jambu biji & Belimbing \\
\hline Tanpa & Warna (Bening) & $17,00 \mathrm{~b}$ & $21,20 \mathrm{ab}$ & $26,20 \mathrm{a}$ \\
\multirow{2}{*}{ Hijau } & $\mathrm{B}$ & $\mathrm{B}$ & $\mathrm{C}$ \\
\multirow{3}{*}{ Kuning } & $24,40 \mathrm{~b}$ & $33,00 \mathrm{a}$ & $34,60 \mathrm{a}$ \\
& $\mathrm{AB}$ & $\mathrm{A}$ & $\mathrm{B}$ \\
& $33,20 \mathrm{~b}$ & $40,80 \mathrm{ab}$ & $43,40 \mathrm{a}$ \\
& $\mathrm{A}$ & $\mathrm{A}$ & $\mathrm{A}$ \\
\hline
\end{tabular}

Keterangan: Nilai tengah yang diikuti oleh huruf yang sama dinyatakan tidak berbeda nyata menurut uji BNT pada taraf $=5 \%$. Huruf kecil dibaca mendatar dan huruf besar dibaca menurun

didapatkan dengan penggunaan jus belimbing, Selain itu, penggunaan warna kuning pada papan likat memiliki rata-rata jumlah lalat lainnya yang tertangkap lebih tinggi $(61,00)$ jika dibandingkan dengan tanpa warna $(28,80)$ dan warna hijau $(35,60)$ tanpa menggunakan jus buah. Penggunaan jus jambu biji $(64,60)$, jus belimbing $(70,40)$ dan tanpa jus $(61,00)$ menunjukkan hasil yang tidak berbeda nyata pada papan likat warna kuning. Hasil serupa juga didapatkan dengan penggunaan papan likat tanpa warna. Selain itu, penambahan jus belimbing memiliki nilai yang lebih tinggi $(64,00)$ dan tidak berbeda nyata dengan tanpa jus jambu biji $(51,60)$ jika dibandingkan dengan tanpa jus $(35,60)$ pada papan likat warna hijau. Secara keseluruhan, penggunaan warna kuning pada papan likat dengan penambahan jus belimbing memiliki rata-rata jumlah lalat buah yang tertangkap lebih tinggi $(70,40)$ jika dibandingkan dengan kombinasi lainnya. Jenis lalat lain yang tertangkap yaitu Famili Asilidae, Drosopjilidae, Syrphidae, Tabanidae, Dolichopodidae, Bombyliidae, dan Muscidae.

Serangga Lain Tertangkap. Hasil analisis ragam menunjukkan bahwa terjadi interaksi yang nyata antara pemberian warna dengan jus buah pada perangkap likat terhadap jumlah serangga lain (Tabel 1). Interaksi yang terjadi menyebabkan terdapat perbedaan jumlah serangga lain yang tertangkap pada masing-masing kombinasi perlakuan (Tabel 4). Interaksi W x J (Tabel 4) menunjukkan bahwa warna kuning pada papan likat memiliki rata-rata jumlah lalat lainnya yang tertangkap lebih tinggi $(40,80)$ dan tidak berbeda nyata dengan warna hijau $(33,00)$ jika dibandingkan dengan tanpa warna $(21,20)$ menggunakan jus jambu biji.

Penggunaan warna kuning memiliki nilai yang lebih tinggi $(43,00)$ jika dibandingkan dengan warna hijau $(34,60)$ dan tanpa warna $(26,20)$ menggunakan jus belimbing. Selain itu, penggunaan warna kuning pada papan likat memiliki rata-rata jumlah lalat lainnya yang tertangkap lebih tinggi $(33,20)$ dan tidak berbeda nyata dengan warna hijau $(24,40)$ jika dibandingkan degnan tanpa warna $(17,00)$ menggunakan tanpa jus jambu biji ataupun jus belimbing. Penggunaan jus belimbing memiliki rata-rata jumlah serangga lain tertangkap lebih tinggi dan tidak berbeda nyata dengan penggunaan jus jambu biji jika dibandingkan tanpa penggunaan jus pada seluruh warna papan likat. Secara keseluruhan, penggunaan warna kuning pada papan likat dengan penambahan jus belimbing memiliki rata-rata jumlah lalat buah yang tertangkap lebih tinggi $(70,40)$ jika dibandingkan dengan kombinasi lainnya. Jenis serangga lain yang tertangkap pada perangkap likat ordo Lepidoptera famili Pieridae, Novtuidae, dan Aphididae; ordo Orthoptera famili Acrididae ; ordo Hymeoptera famili Brachonidae; ordo Coleoptera famili Coccinelidae, Curculionidae, Staphylinidae ; ordo Odonata famili Corduliidae; dan ordo Araneae

\section{Pembahasan}

Hasil penelitian menunjukkan bahwa terdapat pengaruh yang nyata kombinasi jenis jus buah dengan warna perangkap terhadap jumlah lalat buah, lalat lain dan serangga lain yang tertangkap (Tabel 2). Perangkap likat berwarna kuning yang dikombinasikan dengan jus belimbing menghasilkan tangkapan lalat buah paling tinggi jika dibandingkan dengan kombinasi lainnya (Tabel 3, Tabel 4, dan Tabel 5). Data ini mengindikasikan bahwa kombinasi warna kuning dengan jus buah belimbing lebih baik dibandingkan dengan kombinasi lainnya untuk memerangkap lalat buah. Kombinasi warna kuning dengan jus buah belimbing juga menghasilkan tangkapan lalat lain dan serangga lain yang lebih tinggi dibandingkan kombinasi warna dan jus buah lainnya.

Perangkap likat warna kuning memberikan tangkapan yang lebih tinggi daripada warna 
lainnya.Warna kuning yang dikombinasikan baik dengan jus belimbing maupun jus jambu biji memberikan hasil tangkapan yang tinggi daripada warna lainnya. Seperti yang ditunjukkan pada penggunaan warna tanpa jus buah menunjukkan warna kuning memberi hasil tangkapan yang lebih tinggi daripada warna hijau dan tanpa warna (bening).

Warna kuning pada perangkap likat mungkin lebih menarik bagi lalat buah, lalat lain, dan serangga lain, sehingga serangga lebih banyak yang mendatangi perangkap dan kemudian tertangkap. Hasil serupa juga dilaporkan oleh Idris dkk. (2012) yang menyatakan bahwa perangkap likat warna kuning dan dipasang secara vertikal manghasilkan tangkapan kutukebul tertinggi dibandingkan dengan perangkap likat warna biru, hijau, merah, putih, dan hitam. Penggunaan perangkap berwarna kuning menarik imago Liriomyza chinensis, sehingga dapat menekan populasi telur dan larva serta intensitas kerusakan tanaman (Soetiarso, 2007). Spektrum warna kuning-hijau (500-600 nm) merupakan kisaran panjang gelombang khusus dari buah matang yang dapat mengundang ketertarikan hama atau serangga untuk datang (Metcalf dan Metcalf, 1992). Warna kuning yang menarik perhatian lalat buah sering digunakan sebagai perangkap (Kalie, 1999).

Penambahan jus buah pada perangkap likat dapat meningkatkan ketertarikan hama untuk masuk ke dalam perangkap likat yang dipasang. Perangkap likat warna kuning dengan penambahan jus buah belimbing mampu untuk mengundang ketertarikan lalat buah, lalat lainnya, dan serangga lainnya sehingga menghasilkan rata-rata jumlah lalat buah $(3,60)$, lalat lain $(70,40)$, dan serangga $(43,00)$ tertangkap lebih tinggi dari kombinasi lainnya. Darmawi Sikumbang dkk. (2000) melaporkan bahwa preferensi lalat buah Bactrocera sp.untuk tempat bertelur adalah lebih tinggi pada jambu biji dibandingkan buah lainnya. Himawan (2003) menyatakan bahwa Bactrocera sp. lebih memilih bertelur pada buah belimbing dan lalat buah ini lebih menyukai warna kuning dan putih dibandingkan warna lainnya. Hal ini dapat terjadi karena ketika buah menjelang masak dan mulai tampak bewarna kuning, lalat buah betina dapat mengenali inangnya untuk bertelur (Muryati dkk,2006).

Penambahan jus buah jambu biji dapat dijadikan alternatif buah lainnya dalam mengendalikan hama yang menyerang pertanaman cabai merah dengan dikombinasikan pada papan likat berwarna kuning. Halhal tersebut dapat menjadi acuan untuk petani dalam mengendalikan hama lalat buah serta dapat dijadikan bahan penelitian lanjutan untuk lebih mendalam mengetahui pengaruh dari warna dan jus buah dari perangkap likat dalam mengendalikan hama. Oleh sebab itu, kombinasi warna kuning dengan penambahan jus buah jambu biji atau jus buah belimbing mampu manarik lebih banyak lalat buah untuk mendatangi perangkap likat. Penggunaan perankap semacam ini pada pertanaman cabai merah mungkin akan dapat mengurangi serangan hama lalat buah dan hama lainnya.

\section{KESIMPULAN}

Kesimpulan dari penelitian ini yaitu penggunaan warna kuning pada papan likat memberikan jumlah tangkapan yang lebih tinggi daripada warna hijau dan bening. Penambahan jus belimbing pada perangkap likat menghasilkan jumlah tangkapan yang lebih tinggi dibandingkan jus jambu biji dan tanpa jus dan Kombinasi perangkap likat warna kuning dengan penambahan jus buah belimbing menghasilkan jumlah tangkapan lebih tinggi daripada penambahan jus jambu biji.

\section{DAFTAR PUSTAKA}

Antari, N.M.D., I. Sumiartha, N.N. Darmiati, I.P. Sudiartha. 2014. Uji Galur dan Varietas Tanaman Cabai terhadap Serangan Hama Lalat Buah (Bactrocera dorsalis Complex) di Dusun Sandan, Desa Bangli, Kecamatan Baturiti, Kabupaten Tabanan. Jurnal Agroekoteknologi Tropika. Vol.3(2): 1-5.

Atakan, E. dan C. Ramazan. 2004. Evaluation of Yellow Sticky Traps at Various Height for Monitoring Cotton Insect Pests. Journal Agriculture. Entomol. Vol.21(1): 1-24

Badan Pusat Statistik. 2016. Luas Panen, Produktivitas, Produksi Tanaman Cabai Merah Seluruh Provinsi. Available online at: http//www.bps.go.id/, [11 September 2016].

Bangun, D.A. 2009. Kajian Beberapa Metode Perangkap Lalat Buah Pada Pertanaman Jeruk Manis di Desa Sukanalu Kabupaten Karo. Skripsi. Universitas Sumatera Utara. Medan.

Cronquist, A. 1981. An Intergrated System of Clasification of Flowering Plants. New York: Columbia University Press.

Direktorat Perlindungan Holtikultura. 2006. Panduan lalat buah. Available online at: http:// ditlin.holtikultura.go.id/buku_peta/bagian_03.html, [3 februari 2016]. 
Ditjen Hortikultura. 2008. Membangun Hortikultura Berdasarkan Enam Pilar Pengembangan. Direktorat Jenderal Bina Produksi Hortikultura. Departemen Pertanian. Jakarta.

Fletcher. 1997. The Biology of Dacinae Fruit Flies. Ann. Rev. Entomol. Vol.32: 115-144.

Gustilin,2008. The Organic Farmer. Available online at: www.infonet-biovision.org, [20 September 2015].

Hardy, D.E. 1997. Family Tephritidae. In: Delfinando, N.D. dan D.E. Hardy, A Catalog of The Diptera of The Oriental Region. Hawai University Press.

Hidayat, P. dan S. Siwi. 2004. Taksonomi dan Bioekologi Bactrocera spp. (Diptera : Tephritidae) di Indonesia. Balai Besar Penelitian dan Pengembangan Bioteknologi dan Sumberdaya Genetik Pertanian. Bogor. Available online at: $\mathrm{http} / \mathrm{www} . \mathrm{spc}$.int/pacifly/control/ biocontrol.htm, [31 September 2016].

Himawan, T. 2003. Studi Populasi Lalat Buah Bactrocera dorsalis complex pada Tanaman Mangga dengan Pola Tanam Monokultur dan Campuran di Jawa Timur. Jurnal HPT. Vol. 1:7176.

Holmer, K dan A. M. Simmons. 2008. Yellow sticky traps catches of parasitoid of Bemisia tabaci (Hemiptera : Aleyrodidae) in vegetable crops and their relationship to in field populations. $J$. Environ. Entomol. Vol.37(2) : 391-9.

Idris, A.B., S.A.N. Khalid, dan M.N.M.R. Partanika. 2012. Effectiveness of sticky trap designs and colours in trapping alate whitefly, Bemisia tabaci (Gennadius) (Homiptera : Aleyroaidae). J. Tropic Agric. Sci. Vol.35 (1) : 127-34.

Indriyanti, D.Rini., Isnaini Yanuarti Nur., Priyono Bambang. 2014. Identifikasi dan Kelimpahan Lalat Buah Bactrocera pada Berbagai Buah Terserang. Journal of Biology \& Biology Education. Vol.6(1): 38-39.

Kalie, M. B. 1999. Mengatasi Buah Rontok, Busuk, dan Berulat. Penebar Swadaya. Jakarta.

Kalshoven, L.G.E, 1981. Pests of crops in Indonesia, Revised and Translated by Van der Laan. PT Ichtiar Baru-Van Hoeve, Jakarta.

Liburd, O.E dan T.W. Nyoike. 2008. Biology and management of aphids in sustainable field production of cucurbits.http://edis.ifas.ufl.edu/ in76/.diakses27 oktober 2016.

Mahrub, E. 1986. Laporan Penelitian Alat Perangkap Serangga Untuk Mempelajari Dinamika Populasi Hama dan Musuh Alami. Fakultas Pertanian Universitas Gadjah Mada. Yogyakarta.

Metcalf, R.L. dan E.R. Metcalf. 1992. Plant Kairomones in Insect Ecology and Control. New York : Chapman dan Hall.

Muryati, H.A. dan W. Jan. 1996. Efektivitas Model dan Ketinggian Perangkap dalam Menagkap Hama Lalat Buah Jantan. Available online at: http:// www.kennisonline. wur.nl/NR/rdonlyres, [15 Desember 2016].

Nawangsih, A. 2003. Cabai Hot Beauty (Edisi Revisi). Penebar Swadaya. Jakarta.

Pasetriyani, E. T. 2010. Pengendalian Hama Tanaman Sayuran dengan Cara Murah, Mudah, Efektif, dan Ramah Lingkungan. Agribisnis dan Pengembangan Wilayah. Vol.2(1): 2010.

Pujiastuti, Y. 2007. Populasi dan Serangan Lalat Buah (Bactrocera Spp.) serta Potensi Parasitoidi pada Pertanaman Cabai Merah (Capsicum Annum L.) di Daerah Dataran Sedang Sumatera Selatan.Tanaman Tropika. Vol.10(2): 17-28.

Putra,N.S. 1997. Hama Lalat Buah dan Pengendaliannya. Kanisius. Yogyakarta.

Sikumbang, D., I.A. Nasution, M. Indarwatmi dan A.N. Kuswadi2000. Pemanfaatan Ragi Produk Lokal untuk Subsitusi Ragi Torula dalam Formulasi Makanan Buatan Larva Lalat Buah Bactrocera carambolae (Drew \& Hancock). Proc. Pertemuan Ilmiah Penelitian dan Pengembangan Aplikasi Isotop dan Radiasi. P3TIR-BATAN. Jakarta.

Siwi, S.S. 2005. Eko-Biologi Hama Lalat Buah. BBBiogen. Bogor.

Siwi, S.S., P. Hidayat dan Suputa 2006. Taksonomi dan Bioekologi Lalat Buah Penting di Indonesia( Diptera : Tephritidae). Balai Besar Penelitian dan Pembangunan Bioteknologi dan Sumber Daya Genetika Pertanian. Bogor.

Soetiarso, T.A., 2007. Teknologi Inovatif Bawang Merah dan Pengembangannya. Prosiding Seminar Nasional Pengembangan Inovasi Pertanian Lahan Marginal. Badan Penelitian dan Pengembangan. Palu, 25 juli 2007 
Susanti, D.A. 2012. Identifikasi Parasitoid pada Lalat Buah Bactroceracucurbitae dalam Buah Pare.Universitas Pendidikan Indonesia. Bandung.

Tarigan, S dan W. Wiryanta.2003.Bertanam Cabai Hibrida Secara Intensif. Agromedia Pustaka. Jakarta. $120 \mathrm{hlm}$. 